\title{
Research on the Financial Management of Colleges under the Treasury Centralized Payment System
}

\author{
Guanzhuo Wang ${ }^{1, \text { a }}$, Daxu Liu ${ }^{1, b}$, Wenqi Qiao ${ }^{1, ~ c}$, Yang Mu ${ }^{1, d}$ \\ ${ }^{1}$ Heilongjiang University of Chinese Medicine, Jiamusi, Heilongjiang, 154002 \\ ${ }^{a}$ email, ${ }^{b}$ email, ${ }^{c}$ email, ${ }^{\text {d email }}$
}

Keywords: Financial Management, Treasury Centralized Payment System

\begin{abstract}
Since the beginning of this century, the centralized payment system has been implemented in China's colleges and universities. After years of promotion, it has been a kind of rigid system arrangement of our country's finance. Although it has been for many years, the financial management system of colleges and universities has generally lacked systematic design and construction. Based on the basic theory of treasury centralized payment system and the theory of centralized payment of treasury in colleges and universities, this paper expounds the present situation and operation mechanism of financial management system after the implementation of treasury centralized payment system in colleges and universities, and brings the centralized payment system to the university The paper analyzes the main problems existing in the financial management of colleges and universities after the implementation of the centralized treasury payment system in colleges and universities, and puts forward a package of systematic construction of the new financial management system of the university.
\end{abstract}

\section{Introduction}

In recent years, the domestic treasury centralized payment system based on the financial management of more research literature, mainly in the following two aspects: First, simply from the implementation of treasury centralized payment, due to changes in the budget to bring the financial difficulties of colleges and universities; Is the implementation of the treasury centralized payment system due to changes in payment methods, colleges and universities to take the management changes. But in response to the implementation of treasury centralized payment system to the financial management of colleges and universities brought about by the change, and from the entire financial management system design, construction aspects of research, there is still a lack. The author has long been engaged in the financial management of colleges and universities, and has witnessed the process of the implementation of treasury centralized payment system in Zhejiang University of Technology and Zhejiang University. It is very important for the current situation of university financial management before and after the implementation of treasury centralized payment system and the contradictions and problems, actively participate in the treasury centralized payment system based on financial management practice and exploration research. With the implementation of the treasury centralized payment system in a more comprehensive and in-depth implementation, how to proceed from the system point of view, proceed with the construction of the financial management system and the top of the innovative design, try to solve the current problems in the financial management of colleges and universities, this research has become very meaningful.

\section{Treasury centralized payment system concept}

Treasury centralized payment system is based on the Treasury single account system, based on the treasury to pay the main form of funds for the financial treasury management system referred to as the short form. Treasury centralized payment system in the world some major market economy countries and regions, such as the United States, France, Italy, Japan, Brazil and other countries have been implemented for many years, China's Taiwan region as early as 1977 began to implement the Treasury centralized payment system. Treasury centralized payment system, in the international community known as the Treasury single account system, but because of different national systems, 
specific to each country, there are different appellation, such as the United States known as the treasury general account, France called the treasury particularly lost, China Taiwan Known as the treasury centralized payment system. But its basic meaning is no big difference, are unified set of treasury single account system, the government all the financial funds through the account system to pay. Under this system, the treasury will have direct control over the entire process of budget allocation, allocation of funds, use, and bank clearing until the funds reach the merchandise and service provider's account. The basic meaning is that the financial sector to establish a unified bank account, the units of the financial funds in the account under the establishment of a separate account to be centralized management, financial funds are no longer allocated to the units scattered, the units can perform their own functions Need to, within the budget within the discretion of the purchase of goods and services, but the payment by the financial sector to operate, in addition to special purposes, the funds must be directly paid to the financial and commodity suppliers. Its significant performance for the budget unit to use funds but can not see the funds; unsupported funds are retained in the Treasury single account, by the financial sector on behalf of the government management operation.

\section{Treasury Centralized Payment System Specific Content}

(1) the financial sector unified the establishment of a single treasury account. Most countries are located in the central bank, and some countries are located in commercial banks. All the financial funds, through the Treasury single account accounting, so that the government funds through an account management.

(2) financial funds in two ways to pay. Fiscal expenditure is financially paid directly or authorized to pay (authorized by the budget unit), through the agent bank to pay the money to the goods and services suppliers or units. The balance of the financial funds is only kept in the Treasury single account.

(3) the financial establishment of a special treasury accounting center, budget executive board and other institutions. The establishment of such specialized agencies can not only ensure the safe and efficient payment of financial funds, so that the financial funds in the payment before the occurrence of a single account in the Treasury, and can get a better treasury cash management benefits.

The Status Quo of University Financial Management System under the Treasury Centralized Payment System

China's financial structure of colleges and universities generally use the linear function system, that is, the Finance Department (or Planning and Finance Department) unified management of the overall financial work of the school, under the management section, accounting department, cashier, the school according to their own specific circumstances of other departments In addition, some schools set up budget management section, financial management section, integrated management section, and some schools have additional audit section, infrastructure finance section, logistics finance section and state-owned assets management section and other departments, and some schools also set up scientific research Management, etc., many colleges and universities have also set up a secondary financial accounting institutions.

At present, China's high school and resource-related business mainly financial, personnel, assets, equipment, books and infrastructure, logistics and other aspects, they are generally separate management by a number of departments, and information processing systems are independent operation. Each of the departments of the university must submit data to the higher authorities, respectively, in accordance with the requirements of various departments to establish their own information processing system. The financial sector involves only a few aspects of finance, or involves a small number of financial, asset and other aspects, in practice, only bear the budget control, accounting and cash cashier and other small financial functions.

In the traditional management mode, the existing university financial management in the school budget management is similar to the budget preparation, university budget management is only the financial department budget management. Colleges and universities generally use the incremental 
budget to allocate budgetary funds, the actual implementation of only increased, the expenditure can not be reasonably controlled, the various departments reported budget data accuracy is low, often manifested as budget distortion; financial sector budget preparation and approval of many can not Timely assessment of the project, the budget is often relatively late, a large number of special funds concentrated in the fourth quarter to pay, likely to cause slow implementation of colleges and universities; budget lack of reward and punishment assessment mechanism, budget management is useless, saving no reward, overruns without penalties, Inefficient, prominent contradictions between departments.

At present, the construction of financial management information system of colleges and universities is often divided into three modes: one is the development of the school itself, the other is the development and construction of the financial software company, and the other is the part of the professional financial software company Construction, part of the school by their own development and construction. As the university gathered a large number of high-end computer, information, network and other high-end talent, many schools according to the situation of the school, the school can easily organize their own development and construction of their own financial information system; but more schools, Unified organization commission, such as Beijing municipal colleges and universities, or their own according to market conditions and related brothers school practices, such as Zhejiang University, commissioned by the professional financial software company development and construction. Therefore, the current university financial information software a wide range of different functions, the overall construction is relatively lagging behind, can only meet the basic basic accounting and management requirements.

\section{Construction of Financial Management System in Colleges and Universities under Treasury Centralized Payment System}

Information network and computerized accounting is the treasury centralized payment system can be successfully achieved the main technical means. As the initiator of the centralized treasury payment system, the financial department should strengthen the network treasury centralized payment software construction efforts to enhance the treasury payment information system financial management functions, so that the treasury centralized payment system functions more perfect, including colleges and universities in the Within the state treasury to focus on the implementation of the unit's financial management work to establish a scientific, effective and quick payment platform. For the centralized payment of the Treasury side of the party, should be based on its own strong information network architecture, based on the Treasury centralized payment system to build a comprehensive financial information management system to protect the treasury centralized payment reform smoothly.

The system is the main financial system of colleges and universities, but also the core system that colleges and universities should first develop and construct to meet the centralized payment system of treasury. Before the implementation of the treasury centralized payment system, the structure of the general financial system of the university includes the basic account accounting function, and the most important project accounting function in the university accounting, as well as accounting, reporting function, bank automatic reconciliation function, etc. Showing the two-dimensional structural features. But with the implementation of the centralized treasury payment system, the original system structure cannot meet the requirements of centralized treasury payment, that is, from the financial treasury port accounting information data processing. According to the treasury centralized payment of the operating process, when the financial sector issued budget targets, colleges and universities to declare with the plan, according to the approval of the situation in the financial system to complete the project; when an authorized payment business, the university first in the financial system query related The balance of the project, first with a bank settlement notes, and then into the Treasury Treasury centralized payment system, apply for a payment order, and then by the payment order and bank settlement notes to zero balance account bank settlement, The third step, colleges and universities in the zero balance of the bank to get back to the one after another into the financial system to deal with accounts to complete the entire process of centralized 
payment. Direct payment business is also the case. In the whole process, colleges and universities in addition to one's own financial system to complete a series of accounting processing, but also increased in the Treasury Treasury centralized payment system to pay the processing, compared to almost repeated before the operation of the entire process. In addition, the most important thing is that the treasury centralized payment system in the budget information, generally to the university financial system is reflected in the project information, and treasury centralized payment system in a budget indicator, because the particularity of teaching and research, In the financial system is often reflected in a large number of projects, but because the Treasury Treasury centralized payment system and the university financial system is two completely different systems, treasury centralized payment system budget indicators with the plan information, budget execution data And other financial systems in the project information is very difficult to directly correspond to and check, such as financial information system, there are some items in the balance, in the Treasury centralized payment system which budget indicators, in the treasury has not completed, it is difficult to reconcile The In order to get rid of the dilemma, it is necessary to build a financial system based on the treasury centralized payment system. The new system to increase access to the treasury treasury centralized payment system, this side of the data will be successful, that is, the new financial system in the structure to increase the Treasury class money (or funding sources) this dimension, to complete the three-dimensional structure. According to the new structure, colleges and universities in the corresponding revision of the project coding rules, the treasury centralized payment system and the university financial system in the data flow is consistent and docking. Colleges and universities in a centralized payment of treasury, only in the new financial system in the accounting treatment, and then automatically through the treasury centralized payment system to generate a payment order, and finally completed by the bank settlement, the middle minus the input accounting, Collection units, bank information and other work, but also solved the two systems to solve the data between the information check.

\section{Conclusion}

To formulate a new financial management system to meet the centralized treasury payment system, and to formulate financial rules and business processes with centralized treasury payment; to optimize the financial management organization which is compatible with the treasury centralized payment system; to build a financial system based on the treasury centralized payment system The information comprehensive management system includes the construction of the financial main system based on the treasury centralized payment system, the construction of the card management system based on the digital campus, the construction of the silver banking settlement payment system based on the online banking payment, the construction of the online reporting system based on the campus network, Construction of financial procurement system based on government procurement, construction of online financial booking system to build financial information integrated management and publishing platform; to establish a centralized treasury payment system to meet the comprehensive budget management system; to build a scientific and rational financial management performance evaluation and risk assessment system ; To establish a new financial accounting system to adapt to the accounting system; to create a system of scientific and financial management training system.

\section{References}

[1] Jiang Yi, Gao Fengyan.To adapt to the treasury centralized payment reform to strengthen the financial management of colleges and universities [J]. Journal of Liaoning Normal University, $2013(01)$

[2] Chen Fangchen. On the Treasury centralized payment to the financial management of colleges and universities [J]. Accountants, 2012 (10)

[3] Weng Xiaoling. Reform and innovation of financial management in colleges and universities [J]. 
Journal of Tianjin Institute of Management, 2011 (06)

[4] Dong Ling, Han Na. Treasury centralized payment on the impact of financial management in colleges and universities [J] .Journal of Shanxi Colleges and Universities Social Sciences, 2011 (04)

[5] Lai Weihua. Treasury centralized payment system on the impact of financial management [J]. Finance and Accounting, 2011 (11) 